\title{
Pendidikan Teologi Lintas Agama dalam Meraih Keluarga Bahagia (Analisis Teori Islam, Kristen, Hindu, Budha dan Konghucu)
}

\author{
Nurhadi \\ Sekolah Tinggi Agama Islam Al-Azhar Pekanbaru
}

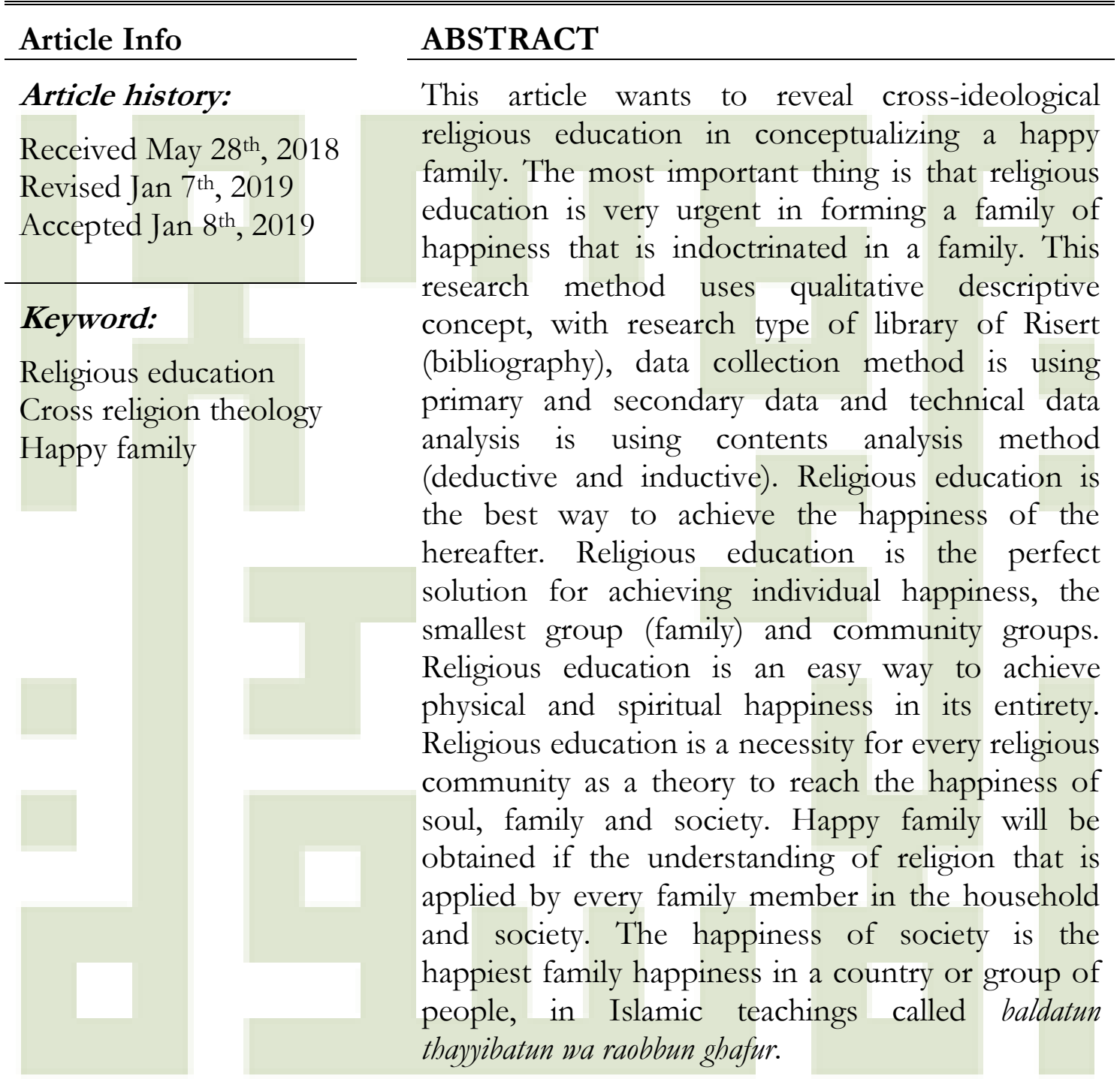

\section{Corresponding Author:}

\section{Nurhadi}

Sekolah Tinggi Agama Islam Al-Azhar Pekanbaru

Email: alhadicentre@yahoo.co.id 


\section{PENDAHULUAN}

Pendidikan adalah sebuah keniscayaan dalam pribadi manusia, tidak seorang pun di dunia ini dibenarkan tidak mendapatkan dan tidak berpendidikan, karena itu adalah hak azasi manusia sebagai fitrah ingin mengetahui sesuatunya. Pendidikan bisa diperoleh dengan berbagai cara, baik secara formal maupun non formal, hal itu tidak menjadi hambatan bagi mausia untuk mencari pengetahuan sebagai bentuk merealisasikan teori pendidikan. Dalam proses pendidikan, pada dasarnya tidak dapat dilakukan hanya dalam satu aspek saja, melainkan meliputi hal ihwal kejadian yang ada di sekitarnya adalah bagian dari proses pendidikan dan pembelajaran. ${ }^{1}$

Jika dicermati secara mendalam, maka proses pendidikan dan pembelajaran manusia terdiri dari tiga aspek sudut pandang, yaitu aspek kepribadian, keluarga dan lingkungan sekitarnya. Dari sudut pandang kepribadian individu, prihal pendidikan dan pembelajaran adalah mindset akal dan pikiran serta nurani dalam menyikapi kebutuhan yang dibutuhkan dalam hidupnya. Semakin banyak seseorang membutuhkan sesuatunya, maka semakin banyak pula ia membutuhkan pengetahuan dan pendidikan, baik diperoleh atau diusahakan dengan

${ }^{1}$ Mustofa Kamil, "Teori Andragogi," dalam Ibrahim, R. Ilmu dan Aplikasi Pendidikan, Vol. 1 (Bandung: Imperial Bhakti Utama, 2007), 291 cara formal, non formal, otodidak atau pengalaman lapangan. ${ }^{2}$

Sedangkan dari sudut pandang aspek keluarga, ini adalah azas dalam kehidupan, bahwa manusia ada karena terlahir, tentunya memiliki orang tua sebagai keluarganya, untuk mengadu dan mencontoh sekaligus tempat meminta naugan dan perlindungan lahir dan batin. Tentunya pendidikan demikian juga, bahwa anak-anak umumnya akan mencontoh dan mengambil iktibar dari kedua orang tuanya. Dalam konsep Islam kedua orang tua dan keluarga adalah sekolah pertama dan guru paling utama. Hal ini disebutkan dalam sebuah riwayat syair:

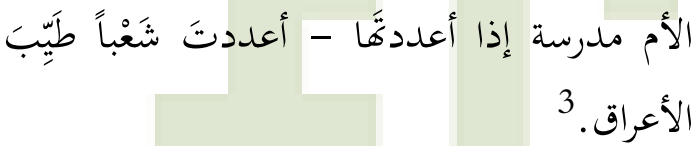

Ibu adalab sebuah madrasah (tempat pendidikan) yang jika kamu menyiapkannya. Berarti kamu menyiapkan (labirnya) sebuah masyarakat yang baik budi pekertinya.

Untuk menjadi sekolah utama bagi para anaknya dibutuhkan berbagai bekal utama. Kesiapan bekal seorang ibu sangat mempengaruhi proses pembelajaran anak yang diasuhnya. Ibarat sebuah instansi sekolah, maka sekolah tersebut akan menjadi sebuah sekolah yang favorit dan unggulan jika pengajarnya profesional dan

2Zakiyah Daradjat, Ilmu Jiwa Agama (Jakarta: Bulan Bintang, 2005), 67.

${ }^{3}$ Syaikh Shaleh al-Fauzan, Makanah alMar'ah fi al-Islam (Riyadh: Maktabah Sunnah, t.th), 5 
berpengalaman. Adapun bekal seorang ibu menjadi sekolah dan guru pertama bagi anak-anaknya adalah membekali anaknya dengan iman dan taqwa, ilmu dan pengalaman serta sabar dan tawakkal.

Teori di atas didukung dengan hadis Nabi SAW.:

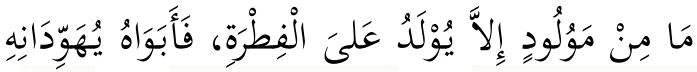

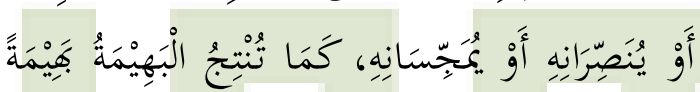

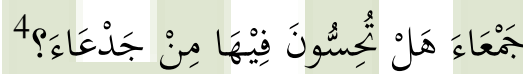

"Tidaklah setiap anak yang lahir kecuali dilabirkan dalam keadaan fitrah. Maka kedua orangtuanyalah yang akan menjadikannya sebagai Yabudi, Nasrani, atau Majusi. Seperti hewan melabirkan anaknya yang sempurna, apakah kalian melibat darinya buntung (pada telinga)?" 5

Syair dan hadis di atas menunjukkan betapa pentingnya pendidikan dan pengajaran dalam keluarga, bahkan hal itu menjadi faktor utama dalam proses pembelajaran dan pendidikan dimasa yang akan datang.

Sudut pandang aspek terahir adalah lingkungan sekitanrya menjadi acuan juga dalam pendidikan dan pembelajaran, namun hal itu bisa diminimalisir dan difilter oleh pengarahan kedua orang tuanya, sehingga aspek lingkungan tidak

${ }^{4}$ Hadits diriwayatkan oleh Al-Imam Malik dalam Al-Muwatbtha' (No. 507); AlImam Ahmad dalam Musnad-nya (No. 8739); Al-Imam Al-Bukhari dalam Kitab al-Jana 'iz. (No. 1358, 1359, 1385), Kitab al-Tafsir (No. 4775), Kitab al-Qadar (No. 6599); Al-Imam Muslim dalam Kitab al-Qadar (No. 2658).

${ }^{5}$ Ma'mur Daud, Terjemah Hadis Shabih Muslim, Jilid IV (Jakarta: Widjaya, 1984), Cet. 1, 243 terlalu mendominan, supaya anakanak tetap terkontrol, lagi-lagi ini adalah peran kedua orang tuanya dalam mendoktrin anaknya dalam ideologinya. Doktrin orang tua sangat mempengaruhi pergaulan anak dalam lingkungan masyarakat dan sekitarnya. Maka dari ketiga aspek ternyata kedua orang tua adalah sentral utama dalam membentuk anak menjadi baik dan berakhlak, tentunya hal itu menjadi dambaan setiap orang tua, juga menjadi faktor kebahagiaan keluarganya. ${ }^{6}$

Undang-Undang Sistem Pendidikan Nasional No. 20 Tahun 2003 Bab 1 Pasal 1 dinyatakan bahwa pendidikan adalah usaha sadar dan terencana untuk mewujudkan suasana belajar dan proses pembelajaran agar peserta didik secara aktif mengembangkan potensi dirinya untuk memiliki kekuatan spiritual keagamaan, pengendalian diri, kepribadian, kecerdasan, akhlak mulia serta keterampilan yang diperlukan dirinya, masyarakat, bangsa, dan negara. ${ }^{7}$

Keberhasilan anak adalah keberhasilan orang tua, karena keberhasilan anak tidak serta merta tanpa didahului dengan interpensi kedua orang tuanya dalam mengantarkan harapan mulia yang diinginkan keduanya dan cita-cita yang akan diraihnya, yaitu kebahagiaan hidupnya. Ini menjadi

${ }^{6}$ Zakiyah Daradjat, Pendidikan Agama dan Akblak bagi Anak dan Remaja (Jakarta: PT logos Wacana Ilmu, 2001), 6

${ }^{7}$ Undang-undang tentang SISDIKNAS dan Peraturan Pelaksanaannya 2000-2004 (Jakarta: CV. Taminta Utama, 2004), 4 
bukti kebahagiaan keluarga mereka, yaitu orang tua dan anak-anak. Maka untuk meraih bahagia keluarga harus ditopang ketiganya dengan baik dan benar sesuai dengan tuntunan ajaran agama. Yang pada dasarnya semua agama mengajarkan kebaikan, walaupun dalam prosesnya kadangkadang di luar kehendak dan hasilnya juga di luar dugaan. Namun hal terpenting bahwa pendidikan keagamaan atau pendidikan agama sangat urgen dalam membentuk keluarga bahagia. ${ }^{8}$ Oleh karena itu, penulis mencoba menyingkap tabir paradigma keagamaan lintas teologi dalam mewujudkan keluarga bahagia.

\section{LANDASAN TEORI}

\subsection{Pendidikan Keagamaan (Teologi Pendidikan)}

Pendidikan keagamaan dalam dunia pendidikan lebih dikenal dengan pendidikan teolog atau teologi pendidikan. Walaupun penggunaan istilah teologi lebih banyak digunakan dalam ajaran agama Nasrani dalam konteks keIndonesiaan. ${ }^{9}$ Di kalangan umat muslim, biasanya digunakan istilah ilmu kalam atau ilmu tauhid dan ilmu keagamaan. ${ }^{10}$

Teologi menurut bahasa Yunani gabungan dua kata, yaitu theos (Allah)

${ }^{8}$ Fuad Ikhsan, Dasar-Dasar Kependidikan (Jakarta: Rineka Putra, 2005), 18.

'Imam Syafe'i, "Teologi Pendidikan: Epistemologis, Ontologis, Dan Aksiologis," Ijtimaiyya, Vol. 6, No. 2 (2013): 2

${ }^{10}$ Suroya Kiswati, Aljuwaeni Peletak Dasar Teologi Rasional dalam Islam (t.t.: Gelora Aksara Pertama, t.th.), 45 dan logos (logika), sehingga menjadi theologia yang artinya suatu catatan atau wacana tentang para tuhan, dewa atau Allah. ${ }^{11}$ Adapun defnisi teologi adalah ilmu pengetahuan metodis, sistematis, dan koheren tentang hal ihwal seluruh penciptaan dalam indera nyata berdasarkan nilainilai iman dan keyakinan. Menurut William L. Reese teologi merupakan sebuah disiplin ilmu yang meletakkan kebenaran wahyu, lewat argumen filsafat dan ilmu pengetahuan yang independen (theology to be a discipline resting on revealed truth and independent of both philosophy and science"). ${ }^{12}$ Amin Abdullah berpendapat teologi adalah suatu ilmu yang membahas tentang suatu keyakinan yang sangat fundamental dalam kehidupan beragama, yaitu suatu ilmu pengetahuan yang paling otoritatif, di mana semua hasil penelitian dan pemikiran harus sesuai dengan alur pemikiran teologis, dan jika terjadi perselisihan, maka pandangan keagamaan yang harus dimenangkan. ${ }^{13}$

Teologi merupakan disiplin ilmu, karenanya selalu berupaya merefleksikan hubungan antara Allah dan hambaNya (manusia), keinginan manusia untuk berteologi dikarenakan keinginan dalam memahami dan merealisasikan ke-

${ }^{11}$ Imam Syafe'i, "Teologi Pendidikan.... ${ }^{12}$ William L. Resse, Dictionary of Philosophy Religion, (USA: Humanities Press Ltd, 1980), 28-29.

${ }^{13}$ Amin Abdullah, Studi Agama: Normativitas atan Historisitas (Yogyakarta: Pustaka Pelajar, 1999), 10. Lihat juga Imam Syafe'i, Teologi Pendidikan ... 
yakinannya secara sempurna. ${ }^{14}$ Akan tetapi sebenarnya teologi bukanlah agama dan bahkan tidak sama dengan ajaran dalam sebuah agama, karena dalam teologi terdapat banyak unsur-unsur "intellectus quaerens fidem" (akal meneliti dan menganalisa isi keyakinan dan iman) yang dapat memberikan dampak secara substansial untuk menyatukan antara akal pikiran dan keyakinan iman, iptek dan imtaq, yang pada intinya sangat bermanfaat bagi kehidupan umat manusia. ${ }^{15}$

Idealnya tujuan pendidikan perspektif teologi pendidikan keagamaan adalah mencetak generasi rabbani menurut teologi Islam, yaitu generasi yang memiliki kesadaran bahwa dirinya adalah hamba tuhan Allah. ${ }^{16} \quad$ Allah sebagai Tuhan Pencipta dan manusia serta lingkungan sekitarnya, memiliki hubungan timbal balik dalam konteks pembentukan insan kamil (yang berakhlak mulia). ${ }^{17}$ Sehingga kesadaran manusia tersebut dapat menghindarkan diri dari penghambaan pada ilmu pengetahuan maupun makhluk lainnya, akhirnya

14Ibid., 3

${ }^{15}$ Anita Kusuma Wardana, "Filsafat dan Teologi," http://filsafat.kompasiana. com/2011/01/20/filsafat-dan-teologi/,

(Diakses dan diunggah Selasa tanggal 22 Agustus 2017).

16Pembentukan akblaq al-karimah sebagai upaya menumbuh-kembangkan nilai-nilai Ilahiyah pada diri manusia atau dengan kata lain membantu untuk dapat memanusiakan manusia dan membebaskannya dari alienasi peran kemanusiaannya dan kehidupan. Lihat Imam Syafe'i, Teologi Pendidikan..., 14-15

17Jalaluddin, Teologi Pendidikan (Jakarta: Raja Grafindo Persada, 2001), 9 muncullah manusia yang beriman dan bertakwa hanya kepada Allah SWT, dan sosok seperti inilah yang disebut insan kamil sebagimana yang tercermin dari kepribadian Rasulullah SAW. ${ }^{18}$

Pakar teologi pendidikan Jalaluddin berpendapat bahwa manusia ciptaan Allah SAW. paling istimewa dan sempurna dengan diberikan akal dan nafsu, serta beban dan tanggung jawab yang diamanatkan kepadanya. ${ }^{19}$ Dalam memaksimalkan potensi diri manusia, Allah SW'T memberikan tarbiyah atau pelajaran. Apapun tindak tanduk perbuatan, sikap, pemikiran dan lainnya yang dilakukan manusia, semuanya bermuatan tarbiyah dengan tujuan untuk tetap memelihara agar manusia bisa menjadi insan kamil. ${ }^{20}$

Secara teoretis, grand theory tarbiyah yang ada dalam al-Qur`an dapat dibagi menjadi dua model, yaitu tarbiyah umum dan tarbiyah khusus. Tarbiyah umum merupakan proses pembinaan dan pemeliharaan Allah kepada seluruh makhluk-Nya dengan cara, seperti menciptakan, memberikan rezeki, dan membimbing semua makhluk-Nya untuk melakukan hal-hal yang baik agar mereka bisa bertahan hidup di dunia

${ }^{18}$ Lihat surah al-Qalam ayat 4 dan alAhzab ayat 21, yang artinya: Dan Sesunggubnya kamu benar-benar berbudi pekerti yang agung. (Q.S. Al-Qalam: 4) Sesunggubnya Telab ada pada (diri) Rasulullab itu suri teladan yang baik bagimu. (Q.S. Al-Ahrab: 21). Departemen Agama RI, AlQur'an dan Terjemahan (Semarang: Toha Putra, 2005), 960 dan 670

${ }^{19}$ Jalaluddin, Teologi Pendidikan ..., 12.

20Ibid. 
ini. Sedangkan tarbiyah khusus merupakan pemeliharaan dan pendidikan keimanan yang secara khusus ditujukan untuk para Nabi dan Rasul serta para aulia-Nya. Menurut pendapat lain, ${ }^{21}$ pemeliharaan Allah yang digali dari kata "rabba," dapat diklasifikasikan menjadi dua macam berdasarkan sasarannya, yaitu: 1) kepada manusia, sebagai makhluk yang memiliki potensi rohani, maka tarbiyah diartikan dengan proses pemberian nafsu dengan berbagai kenikmatan, pemeliharaan hati nurani dengan berbagai kasih sayang, bimbingan jiwa dengan hukum-hukum syariah, dan pengarahan hati nurani dengan berbagai etika kehidupan, serta penerangan rahasia hati dengan hakikat pelita; 2) kepada alam semesta, yang tidak memiliki potensi rohani, maka tarbiyah diartikan dengan pemeliharaan dan pemenuhan segala yang dibutuhkan serta menjaga sebab-sebab yang menjadikan eksistensinya. ${ }^{22}$

Melihat penjelasan di atas, kata "rabba" menyimpan makna hakikat yang sangat besar dan dalam untuk keberlangsung kehidupan seluruh makhluk, perkembangannya dan keteraturannya, seluruhnya tidak terlepas dari rububiyah (pendidikan) dari Allah, yaitu sifat dari asma Rabb. Kata "rabba" jika ditinjau dari asal katanya secara gramatikal, maka ia dalam kategori fi'il dan isim dalam alQur`an, maka akan ditemukan dalam

${ }^{21}$ Ismail Haqi al-Barusawi, Tafsir Rub alBayan, Juz I (Beirut : Dar al-Fikr, t.th), 13.

22Ibid.
Q.S. Al-Isra': 24, al-Syu'ara': 16, alFatihah: 2, dan Ali 'Imran: 79. Berikutnya, jika ayat-ayat tersebut dianalisa dan dikaji serta dihubungkan dengan konsep tarbiyah, khususnya unsur subyek (murabbi) adalah Allah dan manusia juga obyeknya (mutarabbi) (malikat, manusia, jin, tumbuhan, binatang dan lainya) dan (bayi/anak kecil/ anak tiri, manusia, binatang dan kayangan). ${ }^{23}$

Sebenarnya pendidikan sangat bernilai ibadah karena tugas pendidikan merupakan bagian dari tugas kekhalifahan manusia di muka bumi ini, juga pendidikan bagian dari kewajiban menuntut ilmu. Pendidikan dilakukan tanpa batas dan waktu bahkan sepanjang hayat dengan selalu mengatur dan mengembangkan kurikulum atau materi, metode, media, strategi dan sebagainya berdasarkan konseptual yang ada dalam al-Qur`an maupun hadis. ${ }^{24}$

Instrumen dalam teologi pendidikan adalah Ilmu Tauhid atau Ilmu Kalam ditambah ilmu bantu meliputi 'Ulum al-Qur'an, Filsafat Pendidikan, Ilmu Pendidikan, dan Psikologi Pendidikan. Pelaksanaan dan pertanggung-jawaban pendidikan

${ }^{23}$ Dedeng Rosyidin, Zaenal Mudzakir, dan Masor, "Konsep Pendidikan dalam alQur'an,” http:/ / file.upi.edu/direktori.pdf, (Diakses tanggal 22 Agustus 2017).

24Serli Mahroes, "Konsep Rangka

Bangun Teologi Pendidikan, Falsafah Pendidikan, Ilmu Pendidikan, dan Tafsir Pendidikan," http://serlimahroes. blogspot. co. id/2011/06/konsep-rangka-bangun-teologipendidikan.html, (Diakses Selasa 22 Agustus 2017). 
tidak hanya pada sesama manusia, melainkan juga harus kepada Allah SWT. Sumber utama teologi pendidikan Islam adalah al-Qur`an dan Hadis. Dengan pendekatan dan metode yang bersifat humanisteosentris, yaitu pendidikan berorientasi pada fitrah dan kebutuhan primer manusia. ${ }^{25}$

\subsection{Keluarga Bahagia}

Kelompok primer terkecil dalam masyarakat adalah keluarga, yang merupakan suatu group kelompok yang terbentuk (terjadi) dari hubungan laki-laki dan perempuan (perkawinan) yang berlangsung lama, untuk melahirkan, membesarkan dan mendidik anakanak menjadi baik menurut versi keduanya, itulah kesatuan sosial masyarakat terkecil. Masing-masing kesatuan tersebut (keluarga) mempunyai banyak keasamman sifat, di mana saja dan kapan saja dalam satuan masyarakat. ${ }^{26}$ Manusia diciptakan berpasangan, untuk mewujudknya agar saling melengkapi dalam kehidupan maka disyaritkan kawin (pernikahan), yang merupakan salah satu poin penting dalam menggapai kebahagiaan bersama dalam wadah keluarga. ${ }^{27}$ Hubungan perkawinan juga melibatkan tanggung jawab mendasar lainnya, sebagai suami isteri memiliki tanggung jawab yang sama dalam memenuhi kebutuhan biologis (seks),

\footnotetext{
${ }^{25}$ Ibid.

${ }^{26}$ Hartono, Arnicun Aziz, Imu Sosial Dasar (Jakarta: Bumi Persada. 1990), 79

${ }^{27}$ Abdul Qadir Djaelani, Keluarga Sakinah (Surabaya: Bina Ilmu, 1995), 41
}

dan tidak melakukan pelanggaran untuk pemenuhan kebutuhan itu. ${ }^{28}$

Ungkapan pernikahan atau perkawinan tidaklah bisa terlepas dari istilah orang tua, artinya bahwa hasil dari perkawinan antara laki-laki dan perempuan melahirkan anak. Maka identitas laki-laki dan perempuan tersebut beralih menjadi orang tua. Maka orang tua mempunyai peran yang sangat penting diharapkan juga dihargai oleh anak-anaknya, suatu pemenuhan kebutuhan manusiawi sebagai sebuah keluarga. Akibat dari perkawinan adalah melahirkan keturunan sebagai penerus (pewaris) keduanya, maka anak adalah pointer dalam menggapai behagia dalam rumah tangga (keluarga). ${ }^{29}$ Lalu apa sebenarnya kebahagiaan itu?.

Dalam Kamus Arab-Indonesia, Mahmud Yunus mengidentifikasikan bahagia secara etimologi adalah falabun, falah dan muflibun artinya kemenangan atau kebahagiaan, bahagia atau berhasil dari maksudnya atau tujuanya. ${ }^{30}$ Dalam bahasa Inggris kebahagiaan (bappiness, Jerman: gluck, Latin: felicitas, Yunani: eutchia, eudaimonia, Arab: falah, sa'adab), dalam berbagai bahasa Eropa dan Arab menunjukan keberuntungan dan kejadian baik. ${ }^{31}$

Sebagian orang menamakan keluarga bahagia dengan keluarga

28Suzanne Haneef, Islam dan Muslim (Jakarta: Pustaka Firdaus, 1993), 261

${ }^{29}$ Ibid., 262

${ }^{30}$ Mahmud Yunus, Kamus Arab Indonesia (Bandung: Hidakarya, 1990), 323

31Jalaludin Rakhmat, Meraib Kebahagiaan (Bandung: Simbiosa, Rekatama Media, 2004), 98. 
sejahtera. Kesejahteraan menurut Depdiknas adalah hal atau keadaan sejahtera, aman, selamat, dan tentram. $^{32}$ Menurut BKKBN, keluarga sejahtera adalah keluarga yang dibentuk berdasarkan perkawinan yang sah, mampu memenuhi kebutuhan hidup spiritual dan materi yang layak, bertaqwa kepada Tuhan Yang Maha Esa, memiliki hubungan yang selaras, serasi, dan seimbang antar anggota dan antar keluarga dengan masyarakat dan lingkungan. ${ }^{33}$ Kesejahteraan keluarga tidak hanya menyangkut kemakmuran saja, melainkan juga harus secara keseluruhan sesuai dengan ketentraman yang berarti dengan kemampuan itulah dapat menuju keselamatan dan ketentraman hidup. ${ }^{34}$

Setiap orang menginginkan hidup bahagia, baik dunia maupun akhirat. Sebagian ada yang puas dengan kebahagiaan dunia, ada juga yang mendambakan kebahagiaan akhirat tanpa terlalu mempedulikan kehidupan dunia, dan ada mengharapkan kebahagiaan dunia akhirat. Banyak orang menganggap, bahwa orang miskin yang hidup berkekurangan tidak bahagia, namun sesungguhnya bisa berbahagia dengan keadaannya, tergantung jiwa dan paradigama dalam men-

32Depdiknas, Kamus Besar Bahasa Indonesia (Jakarta: Balai Pustaka, 2001), 1011

${ }^{33} \mathrm{BKKBN}$, Pembangunan Keluarga Sejahtera di Indonesia Berdasarkan UU No.10 Tahun 1992 dan GBHN tahun 1993 (Jakarta: Kantor Menteri Kependudukan/BKKBN, 1994), 5

${ }^{34}$ Kasriyati, Membangun dan Membina Keluarga Sejahtera Mandiri (t.tp: t.p, t.th), 3 terjemahkan apa itu bahagia. Begitu juga sebaliknya, tak sedikit orang kaya raya hidup serba berkecukupan, tidak pernah mendapatkan kebahagiaan dengan apa yang telah dicapainya. Hal ini disebabkan karena kebahagiaan adalah sesuatu yang relatif dan abstrak, tidak bisa dilihat atau diraba, kebahagiaan hanya bisa dirasakan oleh hati yang individu yang bersangkutan. ${ }^{35}$ Dalam perkembang-nya kata "bahagia" dan "senang" menjadi tren seolah-olah kedua kata itu saling sepadan. Biasanya orang bahagia memang memerlukan banyak kesenangan, tetapi orang yang sedang menikmati kesenangan belum tentu bahagia. Sangat banyak orang yang tersenyum, tertawa, bergurau, tapi hal itu untuk menyembunyikan kemelut duka dalam hatinya serta luka yang parah dalam jiwanya. ${ }^{36}$

Adat kebiasaannya orang bahagia pasti senang tetapi tidak semua yang senang pasti bahagia. Lalu apa yang membedakan kesenangan dan kebahagian. Menurut Jalaludin Rakhmat, yang mengutip dari Norman E. Rosenthal dalam bukunya The Emotional Revolution, kesenanagan adalah pengalaman sekilas, yang berkaitan dengan ganjaran tertentu. Kebahagiaan adalah keadaan yang berlangsung lebih lama, yang berhubungan dengan penilaian pada kehidupan secara keseluruhan. Orang

${ }^{35}$ Aidh Abdullah al-Qarni, Berbahagialah, Terj. Samson Rahman (Jakarta: Pustaka AlKautsar, 2004), Cet. 1, x

36 Jalaludin Rahmat,

Meraih 
bahagia mengalami kesenangan dalam kehidupannya sehari-hari, di lain hal, kesenangan tidak membawa kepada kebahagiaan bila tidak sejalan atau bertentangan dengan tujuan seseorang. ${ }^{37}$ Konsep kebahagiaan yang dikemukakan di atas, pada dasarnya merupakan pengalaman diri sendiri, dan hanya diri sendirilah yang mengalami kebahagiaan tersebut. Karena boleh jadi seseorang mengatakan bahwa ia senang lalu dikatakan bahagia, justru orang yang senang terkadang menutupi kesedihannya dengan menyenangkan dirinya, dan ini tidak termasuk kebahagiaan. ${ }^{38}$

\section{METODE PENELITIAN}

\subsection{Pendekatan dan Jenis Penelitian}

Pendekatan penelitian ini menggunakan metode kualitatif, ${ }^{39}$ sedangkan jenisnya library research (penelitian kepustakaan). ${ }^{40}$

37Ibid., hlm. 184

${ }^{38}$ Syamsul Ma'arif, “Konsep Al-Qur'an Tentang Keluarga Bahagia, Skripsi (Jakarta: Universitas Islam Negeri Syarif Hidayatullah Jakarta, 1431 H/ 2010 M), 14

${ }^{39}$ Lexy J. Moleong dalam bukunya mengutip Bogdan dan Taylor mendefinisikan metodologi kualitatif sebagai prosedur penelitian yang menghasilkan data deskriptif berupa kata-kata tertulis atau lisan dari orangorang dan prilaku yang dapat diamati. (Lihat Lexy J. Meleong, Metode Penelitian Kualitatif (Bandung: Remaja Rosda Karya, 2011), 29

40Penelitian kepustakaan itu lebih memerlukan olahan filosofis dan teoritis daripada uji empiris di lapangan, karena sifatnya teoritis dan filosofis, penelitian kepustakaan ini sering menggunakan pendekatan filosofis (philosophical approach) daripada pendekatan yang lain. Lihat Noeng

\subsection{Data dan Sumber Data}

Data dan sumber data dalam penelitian ini terdiri dari dua data, yaitu data primer buku-buku pendidikan teologi dan filsafat agama juga teori kebahagiaan dan data sekunder adalah buku-buku filsafat ilmu, dan logika serta lainya. ${ }^{41}$

\subsection{Teknik Pengumpulan dan Analisi Data \\ Metode pengumpulan datanya} adalah secara deskriptif kualitatif dan teknis analisis datanya adalah memakai metode contents analysis ${ }^{42}$ dan filsafat ilmu ${ }^{43}$ dan logika (deduktif $\&$ induktif). ${ }^{44}$

Muhadjir, Metodologi Penelitian Kuantitatif (Yogyakarta: Rake Sarasin, 1996), 169. Lihat juga Burhan Bungin, Penelitian Kualitatif: Komunikasi, Ekonomi, Kebijakan Publik dan Ilmu Sosial Lainnya (Jakarta: Kencana, 2008), 121. Lihat Juga Sugiono, Memahami Penelitian Kualitatif (Bandung: ALFABETA, 2005), 329. Lihat Juga Mestika Zed, Metode Penelitian Kepustakaan (Jakarta: Yayasan Obor Indonesia, 2004), 1

${ }^{41}$ Karena kajian ini adalah kajian teoritis filsafat ilmu dan logika tentang pendidikan Islam.

${ }^{42}$ Menurut Berelson \& Kerlinger, analisis isi merupakan suatu metode untuk mempelajari dan menganalisis komunikasi secara sistematik, objektif, dan kuantitatif terhadap pesan yang tampak. Lihat Rachmat Kriyantono, Teknik Praktis Riset Komunikasi (Jakarta: Kencana Prenada Media Grup, 2010), 232-233. Lihat juga Syukur Kholil, Metodologi Penelitian (Bandung: Citapusaka Media, 2006), 51. Lihat juga Husein Umar, Metode Riset Komunikasi Organisasi: Sebuab Pendekatan Kuantitatif Dilengkapi dengan Contoh Proposal dan Hasil Riset Komunikasi Organisasi Jakarta: Gramedia Pustaka Utama, 2002), 44

${ }^{43}$ Mendefenisikan kajian isi sebagai teknik penelitian untuk keperluan mendeskripsikan secara objektif, sistematis dan 


\section{HASIL PENELITIAN DAN PEMBAHASAN}

\subsection{Kebahagiaan dalam Lintas Teologi}

Islam mengajarkan agar selalu berkasih sayang antar sesama yang merupakan akhlak mulia. Sehingga Islam senantiasa mengedepankan rasa kasih sayang dan cinta kepada seluruh insan, bahkan seluruh makhluk di alam semesta ini, terlebih kepada Allah SWT adalah Tuhan Yang Maha Pengasih dan Penyayang kepada hamba-Nya melebihi kasihnya seorang ibu kepada anaknya. Hal ini dijelaskan dalam ayat al-Qur'an seperti firman Allah yang artinya: "Wahai orang-orang yang beriman, janganlab kamu memakan harta riba yang terlipat ganda dan bertaqwalah kamu sekalian kepada Allah supaya kamu berbahagia,"45 "Hai orang-orang yang beriman, janganlab kamu saling

kuantitatif tentang menifestasi komunikasi. Lihat: Noeng Muhadjir, Metodologi ..., 76-77

${ }^{44}$ Logika diturunkan dari kata sifat "logike" (Bahasa Yunani) yang berhubungan dengan kata benda "logos" yang artinya fikiran. Lihat Afraniati Affan, Filsafat Logika (Padang: Azka Padang, 2002), 1.

${ }^{45}$ Lihat surah al-Imran ayat 130. Keterngan: yang dimaksud riba di sini ialah riba nasi ${ }^{2} a$. Menurut sebagian besar ulama bahwa riba nasi'ah itu selamanya haram, walaupun tidak berlipat ganda. Riba itu ada dua macam: nasi ab dan fadbl. Riba nasi ab ialah pembayaran lebih yang disyaratkan oleh orang yang meminjamkan. Riba fadhl ialah penukaran suatu barang dengan barang yang sejenis, tetapi lebih banyak jumlahnya Karena orang yang menukarkan mensyaratkan demikian, seperti penukaran emas dengan emas, padi dengan padi, dan sebagainya. riba yang dimaksud dalam ayat Ini riba nasi ah yang berlipat ganda yang umum terjadi dalam masyarakat Arab zaman Jahiliyah. Lihat Departemen Agama RI, AlQur'an dan Terjemaban..., 97 memakan barta sesamamu dengan jalan yang batil, kecuali dengan jalan perniagaan yang berlaku dengan suka sama-suka di antara kamu. Dan janganlah kamu membunuh dirimu Sesunggubnya Allah adalah Maha Penyayang kepadamu."46 Dalam Islam ada dua dimensi penting untuk meraih kebahagiaan, yaitu hubungan baik dengan Allah dan hubungan baik dengan manusia, ${ }^{47}$ konsep ini sangat jelas termaktub dalam al-Qur'an surah alImran ayat $112 .{ }^{48}$

Agama samawi Yahudhi (Judaisme) kebahagiaan di dapat tidak harus menghilangkan hasrat, namun kebahagiaan muncul dengan selalu mematuhi hukum Tuhan. Kitab Taurat telah menerangkan: "patubilah mitqvotku (bukum Tuban)

${ }^{46}$ Lihat surah al-Nisa ayat 29. Keterangan: larangan membunuh diri sendiri mencakup juga larangan membunuh orang lain, sebab membunuh orang lain berarti membunuh diri sendiri, Karena umat merupakan suatu kesatuan. Lihat Departemen Agama RI, Al-Qur'an dan Terjemahan..., 122

${ }^{47}$ Teuku Eddy Faisal Rusydi, Psikologi Kebahagiaan (Yogyakarta: Progresif Books, 2007), 9-10

${ }^{48}$ Yang artinya: "Mereka diliputi kebinaan di mana saja mereka berada, kecuali jika mereka berpegang kepada tali (agama) Allah dan tali (perjanjian) dengan manusia, dan mereka kembali mendapat kemurkaan dari Allah dan mereka diliputi kerendahan. Yang demikian itu, karena mereka kafir kepada ayat-ayat Allab dan membunub para nabi tanpa alasan yang benar. Yang demikian itu disebabkan mereka durbaka dan melampaui batas. Keterangan: perlindungan yang ditetapkan Allah dalam Al-Qur`an dan perlindungan yang diberikan oleh pemerintah Islam atas mereka. Yakni: ditimpa kehinaan, kerendahan, dan kemurkaan dari Allah. Yakni: kekafiran dan pembunuhan atas para nabi-nabi. Lihat Departemen Agama RI, Al-Qur'an dan Terjemahan..., 94 
dan lakukanlah semuanya, sehingga dengan demikian kamu telah mengabdikan diri mu kepada Tuhanmu. Jalan yang engkan lalui adalah jalan kebahagiaan dan jalan kedamaian." Sehingga esensi kebahagiaan yang sesungguhnya dalan ajaran agama Yahudhi adalah terletak pada kepatuhan terhadap hukum-hukum Tuhan. ${ }^{49}$

Kabahagiaan menurut agama Kristen substansinya terletak pada perbuatan baik, dan sebaliknya penderitaan itu ada pada perbuatan jahat. Kitab Kristiani dijelaskan bahwa Jesus senantiasa mengajak pengikutnya untuk senantiasa berbuat baik sesama manusia dan melarang berbuat buruk. Ayat-ayat dalam al-Kitab ditemukan tentang cerita kebahagiaan, seperti "barang siapa yang menghina sesamanya, maka dia berbuat dosa, namun berbahagialah orangorang yang selalu menaruh rasa empati dan belas kasiban kepada orang yang menderita." 50

Tujuan hidup menurut agama Hindu adalah maksatam jagadhita ya iti dharma (kebahagian jasmani dan kedamaian rohani). Dalam agama Hindu ada istilah catur purusa artha (empat tujuan hidup manusia) yaitu dharma, artha, kama, dan moksa. ${ }^{51}$ Dalam Brahma Purana, 228: 45 bahwa "dharma artha kama moksa nam sariram sadhanam," artinya tubuh adalah alat

\footnotetext{
${ }^{49}$ Teuku Eddy Faisal Rusydi, Psikologi Kebahagiaan..., 6-7

50Ibid., 8-9

${ }^{51}$ Rudia Adiputra, dkk, Dasar-Dasar Agama Hindu (Jakarta: Ditjen Bimas Hindu, 2004), 113
}

untuk mendapatkan dharma, artha, kama, dan moksa. ${ }^{52}$

Dalam Hindu Dharma, perjalanan hidup manusia di muka bumi ini hanyalah untuk tunduk dan patuh kepada Brahma dan hal itu merupakan alat untuk meraih perdamaian dan keselamatan di dunia dan akhirat. Cara untuk mencapai kebahagiaan dalam Islam adalah dengan jalan beriman, beramal saleh dan beribadah, sedangkan menurut Hindu Dharma adalah dengan melewati jalan sesuai dengan kemampuan yang dimiliki oleh seseorang untuk memilihnya yaitu dengan empat jalan atau "Catur Narga Yoga," yaitu jnana yoga, bhakti yoga, karma yoga dan yang terakhir adalah raja yoga. ${ }^{53}$

Tri hita karana merupakan suatu konsep ajaran untuk menghasilkan keharmonisan dan kebahagiaan yang sempurna dengan jalan interaksi. Tri bita karana berasal dari kata tri (tiga), bita (kebahagiaan), dan karana (sebab). Dengan demikian definisi singkat dari tri bita karana dalam agama Hindu adalah tiga sebab memperoleh kebahagiaan dengan menjaga hubungan yang harmonis dengan ketiga unsur yaitu

52Dharma: mematuhi semua ajaran agama terlihat dari pikiran, perkataan dan perbuatan sehari-hari. Artha: sesuatu bernilai materi yang dapat digunakan untuk memenuhi kebutuhan manusia secar fisik. Kama: kebutuhan hidup berupa sandang, pangan, dan papan serta soaial, spiritual, kesehatan da pendidikan. Moksa atau mukti: kebebasan jiwa rohani yang langgeng. Ibid., 114

${ }^{53}$ Elly Irfiana, Kebahagiaan Menurut Agama Islam Dan Hindu Dharma (Tesis IAIN Sunan Ampel Surabaya, 1998), hlm. abstrak 
Parahyangan (hubungan dengan tuhan), Pahwongan (hubungan dengan sesama manusia) dan Palemahan (hubungan dengan alam sekitar). Dan jika terjalin kehidupan yang harmonis dengan ketiga unsur tersebut maka akan tercapai suatu kehidupan yang bahagia. Dan begitu pula sebaliknya jika hubungan dengan ketiga unsur tersebut tidak harmonis maka kehidupan yang harmonis pun akan sulit dicapai. Dan setelah diketahui juga bahwa ajaran Tri Hita Karana bukanlah suatu ajaran yang baru dalam agama Hindu, akan tetapi adanya perubahan dari isi ajaran yang ada dalam kitab Bhagavad Gita, yang unsur utamanya adalah praja, prajapti dan kamandhuk, yang merupakan dalam aplikasinya sama dengan sama seperti yang diterapkan dalam Tri Hita Karana. ${ }^{54}$

Kebahagiaan menurut sang Buddha bersabda: "wahai para pendeta, inilab kebenaran mulia tentang penghancuran penderitaan." Maksudnya mematikan (penghancuran) nafsu dalam jiwa yang sesungguhnya. Di sini dikesampingkan, dihilangkan, dibebaskan, dari pencapaian untuk membebaskan dahaga, sehingga esensi kebahagiaan atau penderitaan dalam agama Budha terletak pada hasrat dalam meraih sesuatu tujuan, denganya ambisi untuk mencapai sesuatu tidak mendominasi. ${ }^{55}$

Kebahagiaan dalam istilah agama Khonghucu adalah

${ }^{54} \mathrm{Abu}$ Zar al-Gifari, "Kebahagiaan Menurut Ajaran Tri Hita Karana," Artikel Jurnal 34.2.1.1.1626

${ }^{55}$ Teuku Eddy Faisal Rusydi, Psikologi Kebahagiaan..., 5-6 humanisme menurut penulis, karena hamba yang humanis lah yang akan memperoleh kebahagiaan hidup. Humanisme merupakan suatu pendekatan yang melihat bagaimana manusia membangun dirinya untuk melakukan hal-hal positif yang merupakan potensi yang dimiliki setiap manusia. Kemampuan positif di sini erat kaitannya dengan pengembangan emosi positif yang terdapat dalam domain afektif. Emosi adalah karakterisitik yang sangat kuat yang nampak dari para pendidik beraliran humanisme. ${ }^{56}$

Pengertian humanisme dalam agama Khonghucu menurut Ali Syari'ati, adalah humanisme mencitacitakan adanya kebebasan dari penindasan, kesempurnaan hidup, keadilan, kebenaran, kesadaran diri manusia, mendahulukan masyarakat atas individu, esensi kerja, keseimbangan antar konsumsi dan penghasilan, penolakan terhadap kesewenang-wenangan, menolak perang, melindungi peribadatan, menolak kebodohan dan kelemahan, kemampuan memperjuangkan hak hidup, menolak diskriminasi ras dan golongan, dan privilege sosial, yang semuanya adalah cita-cita kemanusiaan yang ada di sepanjang sejarah manusia yang beradab dari kaum intelektual yang bebas dan

\footnotetext{
56Rina Harahap, "Teori Belajar Humanisme," dalam Viviana, Konsep Humanisme Agama Khonghucu Dalam Membentuk Manusia Sempurna (Studi Terhadap Sikap Kemanusiaan Umat Khonghucu di Lithang Bakti Pondok Cabe), Jakarta: Universitas Islam Negeri Syarif Hidayatullah Jakarta 1436 H./2015 M), 19
} 
cinta kemanusiaan, ini menurut penulis inti dari kebahagiaan hidup. ${ }^{57}$ Humanisme dalam agama Khonghucu, merupakan ajaran satya dan tepasarira, yakni hubungan manusia dengan Tuhan, dan hubungan manusia dengan sesama manusia, termasuk juga hubungan manusia dengan alam semesta. Setiap umat harus menjaga keharmonisan tersebut agar terwujud perdamaian abadi dengan adanya kebijaksanaan, cinta kasih, dan keberanian. ${ }^{58}$ Dengan memahami makna kata bumanism di atas, menunjukkan bahwa inti persoaalan yang dibahas dalam humanism adalah manusia itu sendiri, bagaimana membentuk manusia itu menjadi lebih manusiawi, serta pihak mana atau siapa yang bertanggung jawab pada proses pembentukannya. 59

Dari definisi di atas, dapat disimpulkan bahwa kebahagiaan adalah gejolak dalam diri yang menimbulkan emosi dalam bentuk rasa senang. Emosi ini akan keluar jika terdapat emosi positif dari dalam diri. Emosi yang membangkitkan kebahagiaan hanya emosi positif dan kegiatan positif yang berasal dari diri sendiri dan lingkungannya. ${ }^{60}$

${ }^{57 N i n a}$ Asmara, "Humanistik Dalam Agama Khonghucu," Skripsi (Yogyakarta: Universitas Islam Negeri Sunan Kalijaga Yogyakata, 2008), 68

58Viviana, Konsep Humanisme Agama Khonghucu..., 21

${ }^{59}$ Zulfan Taufik, Ilusi dan Harapan „Pembacaan Humanisme Ali Shariati (Jakarta: Impressa, 2012), Cet I, 36

${ }^{60}$ Teuku Eddy Faisal Rusydi, Psikologi Kebahagiaan..., 11-12
4.2. Landasan Historis, Filosofis, Psikologis, Sosiologis, dan Pedagogis tentang Agama Sarana Menuju Kebahagiaan

Beragama bagi seorang hamba (manusia) menurut para pakar teolog merupakan fitrah basyariah. Jika manusia menjalani kehidupan menurut fitrahnya, kebahagiaanlah yang akan didapat. Jika sebaliknya, tentu tidak akan mendapatkan kebahagiaan. Menurut teori sejarah (historis), sepanjang siklus kehidupan manusia, beragama hakikatnya merupakan kebutuhan yang mendasar bagi manusia. Sejarah mencacat banyak kisah umat manusia mencari jati dirinya dan sang penciptanya (Tuhan). Ibnu Thufail salah seorang filosof menguraikan dalam kitabnya bahwa suatu kebenaran dapat ditemukan jika ada keselarasan antara akal pikiran manusia dan nash (wahyu). Manusia dapat mencari Tuhan dengan menggunakan akal pikiran logikanya, dan bisa ketemu dengan Tuhannya (makrifat). Akan tetapi Namun, hal itu harus dikonfirmasi dan disingkronkan dengan firman Tuhan (nash wahyu), agar hakikat penemuannya tidak menyalahi dan berdampak rasa syukur terhadap Allah (Tuhan) atas setiap nikmat yang diterimanya di antara nikmat tersebut adalah bisa menemukan Allah (Tuhan) dengan menggunakan 
akal naluri pikiranya sebagai penyempurna dari makhluk lainya. ${ }^{61}$ Qishshah al-anbiya dalam alQur'an tentang Nabi Ibrahim AS mencari Sang Pencipta (Allah). ${ }^{62}$ Kisah akhir dari pencarian Tuhan adalah dengan merenung (berpikir) dan bertadabbur (meresapi) hal itu membuahkan hasil bahwa Allah (Tuhan) pasti Esa dan Maha Kuasa, sumber kehidupan, pemberi kenikmatan, pelindung dari segala bahaya, dan tempat menggantungkan segala harapan dan keinginan, serta

${ }^{61}$ Fahri Husaini, dkk, Bagaimana Agama Menjamin Kebahagiaan (Makalah Universitas Pamulang (UNPAM), 4

${ }^{62}$ Lihat Q.S. Al-An'am ayat 74-79, yang artinya: Dan (Ingatlab) di waktu Ibrabim Berkata kepada bapaknya, Azar, "Pantaskah kamu menjadikan berbala-berbala sebagai tuban-tuhan? Sesunggubnya Aku melibat kamu dan kaummu dalam kesesatan yang nyata." Dan Demikianlah kami perlihatkan kepada Ibrabim tanda-tanda keagungan (Kami yang terdapat) di langit dan bumi dan (Kami memperlibatkannya) agar dia termasuk orang yang yakin. Ketika malam telah gelap, dia melihat sebuah bintang (lalu) dia berkata: "Inilah Tubanku", tetapi tatkala bintang itu tenggelam dia berkata: "Saya tidak suka kepada yang tenggelam." Kemudian tatkala dia melihat bulan terbit dia berkata: "Inilah Tubanku." Tetapi setelah bulan itu terbenam, dia berkata: "Sesunggubnya jikea Tubanku tidak memberi petunjuk kepadaku, Pastilah Aku termasuk orang yang sesat." Kemudian tatkala ia melihat matahari terbit, dia berkata: "Inilah Tuhanku, Ini yang lebih besar." Maka tatkala matahari itu terbenam, dia berkata: "Hai kaumku, Sesunggubnya Aku berlepas diri dari apa yang kamu persekutukan. Sesunggubnya Aku menghadapkan diriku kepada Rabb yang menciptakan langit dan bumi, dengan cenderung kepada agama yang benar, dan Aku bukanlah termasuk orang-orang yang mempersekutukan Tuban. Keterangan: di antara Mufassirin ada yang berpendapat bahwa yang dimaksud dengan abiihi (bapaknya) ialah pamannya. Lihat Departemen Agama RI, AlQur'an dan Terjemaban..., 199 sumber kebahagiaan. ${ }^{63}$ Renungannya dibenarkan dengan wahyu firman Allah yang diterimanya sehingga pencarian Tuhan (Allah) benar menurut akal pikiran dan juga wahyu (firman Allah). Keseuaian antara akal dan wahyu itulah agama Nabi Ibrahim yakni agama yang rasional dan hanif (penyerahan diri) kepada Tuhan secara total (abdi) yaitu penghambaan jiwa dan raga. Kisah teologis manusia mencari tuhan sebenarnya sangat panjang, hal ini bisa dibuktikan dalam sejarah filasafat, misalnya filosof Aristoteles, Plato, Socrates, Thales, Phitagoras, dan lainya. ${ }^{64}$

Secara historis juga dalam alQur`an menyatakan bahwa "sesunggubnya dalam penciptaan langit dan bumi, silih bergantinya siang dan malam, babtera yang berlayar di laut membawa apa yang berguna bagi manusia, dan apa yang Allab turunkan dari langit berupa air, lalu dengan air itu Ia bidupkan bumi yang sudah mati, dan Ia sebarkan di bumi itu segala jenis hewan, dan pengisaran air dan awan yang dikendalikan antara langit dan bumi; sungguh terdapat tanda-tanda (keesaan

${ }^{63}$ Lihat surah al-Ikhlas ayat $1-4$, yang artinya: Katakanlab: "Dia-lah Allah, yang Maba Esa. Allah adalah Tuhan yang bergantung kepadaNya segala sesuatu. Dia tiada beranak dan tidak pula diperanake.kn. Dan tidak ada seorangpun yang setara dengan Dia." Ibid., 1118

${ }^{64}$ Rifalzi Isa S, "Bab III Bagaimana Agama Menjamin Kebahagiaan?" (http://ajengindah.log.fisip.uns.ac.id/wpcontent/uploads/sites/261/2016/12/waterma rk), 74 
dan keagungan Allah) bagi kaum yang berakal. ${ }^{65}$

Ahli psikologi berpendapat, bahwa manusia membutuhkan agama, ini sesuai dengan argumen alQur`an, bahwa manusia adalah makhluk rohani, jasmani, dan sosial. ${ }^{66}$ Manusia makhluk rohani, membutuhkan ketenangan jiwa, ketenteraman hati dan kebahagiaan rohani. Kebahagiaan rohani hanya akan didapat jika manusia dekat dengan pemilik kebahagiaan yang hakiki yaitu Tuhan (Allah). Menurut teori mistisisme Islam, bahwa Tuhan Maha suci, Maha Indah dan maha segalanya. Tuhan Allah yang Maha Suci tidak dapat didekati kecuali dengan jiwa yang suci, maka sucikanlah hati dari segala kotoran dan sifat-sifat tercela, agar bisa bertemu dengan Tuhan (Allah) ${ }^{67}$ Dalam Hadis Qudsi Allah berfirman, yang artinya "Hambaku senantiasa mendekatkan diri kepada-Ku dengan anNawafil (melaksanakan ibadah-ibadah sunat) sehingga Aku mencintainya. Barang siapa yang telab Aku cintai, maka pendengarannya adalab pendengaran-Ku, penglihatannya adalab penglihatan-Ku, dan tangannya adalah tangan-Ku." 68 Maksud hadis itu tentu saja bahwa orang tersebut dilindungi Allah dan segala permohonan dan doanya akan dikabulkan Allah. ${ }^{69}$

${ }^{65}$ Q.S. Al-Baqarah (2): 164. Departemen Agama RI, Al-Qur'an dan Terjemahan ..., 40

${ }^{6}$ Rifalzi Isa S, "Bab III Bagaimana Agama Menjamin Kebahagiaan...," 75

${ }^{67}$ Ibid.

${ }^{6}$ H.R. Muslim.

${ }^{69}$ Rifalzi Isa S, "Bab III Bagaimana Agama Menjamin Kebahagiaan..."
Sejalan dengan teori psikologi di atas juga teori sosiologis menyatakan bahwa manusia sangat perlu terhadap agama. Argumen ini sesuai karakter manusia, menurut alQur`an, manusia adalah makhluk sosial artinya manusia tidak bisa hidup sendirian, ${ }^{70}$ dan tidak bisa mencapai tujuan hidupnya tanpa keterlibatan orang lain, saling bantu membantu menjadi ciri perilaku makhluk sosial, yaitu hidup tidak terlepas dari kehidupan bermasyarakat. $^{71}$

${ }^{70} \mathrm{Di}$ dalam al-Qur`an dijelaskan kedudukan manusia sebagai makhluk sosial. Ayat-ayat berikut ini menggambarkan kondisi manusia yang demikian. (Q.S Al-Isra /17: 70), (Q.S An-Nisa /4: 1), (Q.S Al-Tin/95: 4), (Q.S. Al-An'am/6: 165), (Q.S. Luqman/31: 28), (Q.S. Al-Baqarah/2: 3), (Q.S. Yunus/10: 14),(Q.S. Shaad/38: 26), (Q.S. Fathir/35: 3), (Q.S. Al-An'am/6: 63), (Q.S. Al-Lail/92: 4-11).

${ }^{71}$ Rifalzi Isa S, "Bab III Bagaimana Agama Menjamin Kebahagiaan..., 76-77. Halhal yang menjadi faktor penyebab manusia harus hidup bermasyarakat: 1). Adanya dorongan seksual, yaitu dorongan manusia untuk mengembangbiakkan keturunan atau jenisnya sendiri. 2). Adanya kenyataan bahwa manusia adalah makhluk yang serba terbatas dan makhluk yang lemah. Untuk menutupi kelemahan dan keterbatasannya, maka manusia perlu bantuan orang lain yang adadi sekitarnya yaitu masyarakat. 3). Karena adanya perasaan senang pada tiap-tiap manusia. Manusia bermasyarakat karena ia telah biasa mendapat bantuan yang berfaedah yang diterimanya sejak ia masih kecil hingga dewasa, misalnya, dari lingkungannya. 4). Adanya kesamaan keturunan, kesamaan teritorial, senasib, kesamaan keyakinan, kesamaan cita-cita, kesamaan kebudayaan, dan lain-lain. 5). Manusia tunduk dan patuh pada aturan dan norma sosial. 6). Perilaku manusia mengharapkan suatu penghargaan dan pengakuan dari orang-orang yang ada di sekitarnya(masyarakat sekitar). 7). Berinteraksi, berkomunikasi dan beradaptasi dengan 
Secara horizontal, manusia butuh berinteraksi dengan sesamanya dan lingkungannya baik flora maupun fauna. Secara vertikal manusia lebih butuh berinteraksi dengan Zat yang menjadi sebab ada dirinya. Manusia dapat wujud/ tercipta bukan oleh dirinya sendiri, namun oleh yang lain. Yang menjadi sebab wujud manusia tentulah harus Zat Yang Wujud dengan sendirinya sehingga tidak membutuhkan yang lain. Zat Yang Wujud dengan sendirinya disebut wujud hakiki, sedangkan suatu perkara yang wujudnya tegantung kepada yang lain sebenarnya tidak ada/tidak berwujud. Kalau perkara itu mau disebut ada (berwujud), maka adalah wujud idhafi. Wujud idhafi sangat tergantung kepada wujud hakiki Itulah sebabnya, manusia yang sebenarnya adalah wujud idhafi yang sangat membutuhkan Zat Yang Berwujud secara hakiki, itulah Allah. Jadi, manusia sangat membutuhkan Allah. Allah lah yang menghidupkan, mematikan, memuliakan, menghinakan, mengayakan, memiskinkan, dan Dialah Allah Yang Zahir, Yang Batin, dan Yang Berkuasa atas segala sesuatu. ${ }^{72}$

Secara alamiah manusia berinteraksi dengan lingkungannya, sebagai pelaku dan sekaligus dipengaruhi oleh lingkungannya. Perlakuan manusia terhadap lingkungannya sangat menentukan

lingkungan merupakan salah satu kebutuhan dasar manusia. 8). Potensi manusia akan berkembang bila hidup di tengah-tengah manusia dan masyarakatnya.

${ }^{72}$ Fahri Husaini, dkk, Bagaimana Agama Menjamin Kebahagiaan..., 4-5 keramahan lingkungan terhadap kehidupannya sendiri. Manusia dapat memanfaatkan lingkungan, tetapi perlu memelihara lingkungan agar tingkat kemanfaatannya bisa dipertahankan bahkan ditingkatkan. Respon manusia dalam menyikapi dan mengelola lingkungannya pada akhirnya akan mewujudkan modelmodel peradaban dan kebudayaan baru. ${ }^{73}$

Manusia juga disebut makhluk sosial-budaya, artinya makhluk yang harus hidup bersama dengan manusia lain dalam satu kesatuan yaitu masyarakat, dan pergaulan tersebut menciptakan kebudayaan sehingga mencukupi kebutuhan hidupnya. Manusia tidak dapat dilepaskan dari kebudayaan, maka di mana ada manusia pasti ada kebudayaan. ${ }^{74}$

Keseimbangan hubungan horizontal dan vertikal, maka manusia akan mendapatkan kebahagiaan. Kebahagiaan diperoleh manakala manusia diterima, dan dihargai oleh lingkungannya dan secara vertikal bisa mendekatkan diri kepada Tuhannya secara baik dan benar. Mendekatkan diri kepada Allah untuk menggapai mardhatillah itulah tujuan hidup manusia sebagai makhluk sosial. Karena manusia berusaha mendekatkan diri kepada Allah, maka disebutlah manusia sebagai 'abdullab (hamba Allah). Karena manusia berusaha menjalin hubungan secara produktif dengan

73Rifalzi Isa S, "Bab III Bagaimana Agama Menjamin Kebahagiaan...," 78

74Ibid. 
sesama manusia dan lingkungannya, dengan cara membangun peradaban yang memajukan martabat manusia, maka disebutlah manusia sebagai khalifatullah (pemimpin atau wakil). Dengan memposisikan diri sebagai Abdullah dan khalifatullah secara integral dan seimbang, maka manusia meraih dan mendapatkan kebahagiaan lahir dan batin serta rohani dan jasmani. ${ }^{75}$

\subsection{Pendidikan Keagamaan dalam Meraih Keluarga Bahagia}

Menganalisa dari pemaparan dalam bahasan sebelumnya, yaitu hakikat kebahagiaan perspektif lintas teologi (agama) yaitu Islam, Yahudi, Kristen, Hindu, Budha dan Khonghucu, serta bahasan yang berkaitan dengan landasan historis, filosofis, psikologis, sosiologis, dan pedagogis tentang agama sarana menuju kebahagiaan, maka hakikat kebahagian menurut para pakar lintas agama (teologi) bertitik tolak dalam nilai-nilai ajaran agama, dengan cara mempelajari, mengetahui dan memahami serta mengamalkan nilai ajaran agama dalam segala sendisendi kehidupan, baik sebagai pribadi individu, dalam kelompok terkecil keluarga serta kelompok umum yang besar yaitu masyarakat. Nilai-nilai ajaran agama harus disinergikan dengan jiwa (rohani), raga (jasmani) dan lingkungan (alam), sehingga ketiganya menjadi kesatuan secara integral, maka akan tercapailah

${ }^{75}$ Ibid., 79 kebahagiaan hakiki yang utuh, bagi diri sendiri, keluarga juga masyarakat.

Pendidikan keagamaan (teologi) atau nilai ajaran agama yang selalu dipelajari, diketahui, dipahami serat diaplikasikan dalam dunia pendidikan sejak dini, dapat menjadi alur menuju kebahagiaan hidup manusia. Pendidikan keagamaan yang didoktrin sejak dini kepada masyarakat lapisan terbawah, yaitu anak-anak, remaja dan dewasa melalui jenjang pendidikan formal atau non formal, sehingga masyarakat dapat memahami pentingnya ajaran agama dalam mengarahkan tujuan hidup dalam meraih kebahagiaan. Kebahgaian individu adalah sentral utama dengan komando nilai ajaran agama yang didapat dalam pendidikan kegamaan, sehingga akan tercermin dijenjang kebahagiaan berikutnya ketika sudah berumah tangga.

Kebahagiaan rumah tangga yang dilandasi dengan ajaran keagamaan akan mengantarkan kebahagiaan dalam keluarga. Sehingga kebahagiaan keluarga tercermin dalam nilai-nilai ajaran agama dari mulai anggota terkecil yaitu anak-anak, orang tuanya dan antara pasangan suami istri. Hal ini akan dengan sendirinya mengalir ke hilir kelompok keluarga besar yaitu cucu-cucu, anak kemanakan, saudara, ipar, mertua, orang tua, kakek dan nenek serta lainya.

Keluarga bahagia akan diperoleh jika pemahaman agama yang diaplikasikan oleh setiap anggota keluarga kecil atau keluarga besar. 
Oleh karena itu, pendidikan agama adalah jalan terbaik dalam meraih kebahagiaan dunia akhirat. Pendidikan agama adalah solusi tepat dalam menggapai kebahagiaan individu, golongan kelompok terkecil (keluarga) dan kelompok masyarakat. Pendidikan agama adalah cara mudah mendapatkan kebahagiaan jasmani dan rohani secara utuh dan seutuhnya. Inilah hakikat kebahagiaan yang di dambakan oleh seluruh pemeluk agama (lintas agama). Maka sebenarnya seluruh ajaran agamanya mengajarkan nilainilai kebaikan dan kebahgiaan bagi pemeluknya (umatnya). Pendidikan keagamaan adalah sebuah keniscayaan bagi setiap ummat beragama sebagai teori menggapai kebahagiaan jiwa, keluarga dan masyarakat. Akhirnya kebahagiaan hanya akan didapat melalui pendalaman ajaran agama dan pengamalannya dalam kehidupan, tanpa ada teori lain yang dapat mengalahkanya. Andaipun ada teori kebahagiaan lain selain teori agama, maka kebahagiaan yang diperoleh hanyalah kebahagiaan semu atau sejenak, tidak kebahagiaan yang kekal dan berkelanjutan dunia dan akhirat.

Kebahagiaan masyarakat adalah kebahagiaan keluarga yang paling diidamkan dalam sebuah negara atau kelompok masyarakat, dalam ajaran Islam disebut baldatun thayyibatun wa raobbun ghafur.

\section{KESIMPULAN}

Dalam Islam, ada dua dimensi penting untuk meraih kebahagiaan, yaitu hubungan baik dengan Allah dan hubungan baik dengan manusia. Esensi kebahagiaan yang sesungguhnya dalan ajaran agama Yahudi adalah terletak pada kepatuhan terhadap hukum-hukum Tuhan. Kabahagiaan menurut agama Kristen substansinya terletak pada perbuatan baik, dan sebaliknya penderitaan itu ada pada perbuatan jahat. Tujuan hidup menurut agama Hindu adalah kebahagiaan jasmani dan kedamaian rohani. Kebahagiaan menurut agama Budha mematikan nafsu dalam jiwa yang sesungguhnya.

Secara historis, filosofis, psikologis, sosiologis, dan pedagogis manusia dipastikan membutuhkan agama. Beragama bagi seorang hamba (manusia) merupakan fitrah manusia. Secara historis, telah digambarkan dalam al-Qur`an. Secara psikologis, manusia membutuhkan agama, manusia adalah makhluk rohani, jasmani, dan sosial. Sejalan dengan teori psikologi itu, sosiologis menyatakan bahwa manusia sangat perlu terhadap agama. Manusia adalah makhluk sosial yang tidak bisa hidup sendirian, dan tidak bisa mencapai tujuan hidupnya tanpa keterlibatan orang lain, saling bantu membantu menjadi ciri perilaku makhluk sosial, yaitu hidup tidak terlepas dari kehidupan bermasyarakat. Manusia juga disebut makhluk sosial-budaya, artinya makhluk yang harus hidup bersama dengan manusia lain dalam 
satu kesatuan yaitu masyarakat, dan pergaulan tersebut menciptakan kebudayaan sehingga mencukupi kebutuhan hidupnya. Keseimbangan hubungan horizontal dan vertical, maka manusia akan mendapatkan kebahagiaan.

Pendidikan agama adalah jalan terbaik dalam meraih kebahagiaan dunia akhirat. Pendidikan agama adalah solusi tepat dalam menggapai kebahagiaan individu, golongan kelompok terkecil (keluarga) dan kelompok masyarakat. Pendidikan agama adalah cara mudah mendapatkan kebahagiaan jasmani dan rohani secara utuh dan seutuhnya. Pendidikan keagamaan adalah sebuah keniscayaan bagi setiap ummat beragama sebagai teori menggapai kebahagiaan jiwa, keluarga dan masyarakat. Keluarga bahagia akan diperoleh jika pemahaman agama yang diaplikasikan oleh setiap anggota keluarga dalam rumah tangga dan masyarakat.

\section{REFERENSI}

[1] Abdullah, Amin, Studi Agama: Normativitas atan Historisitas. Yogyakarta: Pustaka Pelajar, 1999

[2] Adiputra, Rudia, dkk. DasarDasar Agama Hindu. Jakarta: Ditjen Bimas Hindu, 2004

[3] Affan, Afraniati. Filsafat Logika. Padang: Azka Padang, 2002

[4] Al-Barusawi, Ismail Haqi. Tafsir Ruh al-Bayan, Juz I. Beirut : Dar al-Fikr, t.th.
[5] Al-Fauzan, Syaikh Shaleh. Makanah al-Mar'ah fi al-Islam. Riyadh: Maktabah Sunnah, t.th.

[6] Al-Gifari. Abu Zar. "Kebahagiaan Menurut Ajaran Tri Hita Karana." Artikel Jurnal 34.2.1.1.1626.

[7] Al-Qarni, Aidh Abdullah. Berbahagialah. Terj. Samson Rahman. Jakarta: Pustaka AlKautsar, 2004, Cet. 1.

[8] Asmara, Nina. "Humanistik Dalam Agama Khonghucu." Skripsi. Yogyakarta: Universitas Islam Negeri Sunan Kalijaga Yogyakata, 2008

[9] BKKBN. Pembangunan Keluarga Sejabtera di Indonesia Berdasarkan UU No.10 Tabun 1992 dan GBHN tahun 1993. Jakarta: Kantor Menteri Kependudukan/BKKBN, 1994

[10] Bungin, Burhan. Penelitian Kualitatif: Komunikasi, Ekonomi, Kebijakan Publik dan Ilmu Sosial Lainnya. Jakarta: Kencana, 2008

[11] Daradjat, Zakiyah. Ilmu Jiwa Agama. Jakarta: Bulan Bintang, 2005

[12] Daradjat, Zakiyah. Pendidikan Agama dan Akblak bagi Anak dan Remaja. Jakarta: PT logos Wacana Ilmu, 2001.

[13] Daud, Ma'mur. Terjemah Hadis Shabih Muslim. Jilid IV. Jakarta: Widjaya, 1984. Cet. 1.

[14] Departemen Agama RI. AlQur'an dan Terjemahan. Semarang: Toha Putra, 2005. 
[15] Depdiknas. Kamus Besar Bahasa Indonesia. Jakarta: Balai Pustaka, 2001

[16] Djaelani, Abdul Qadir. Keluarga Sakinah. Surabaya: Bina Ilmu, 1995

[17] Haneef, Suzanne. Islam dan Muslim. Jakarta: Pustaka Firdaus, 1993.

[18] Harahap, Rina, "Teori Belajar Humanisme." Dalam Viviana, Konsep Humanisme Agama Khonghucu Dalam Membentuk Manusia Sempurna (Studi Terbadap Sikap Kemanusiaan Umat Khonghucu Di Lithang Bakti Pondok Cabe). Jakarta: Universitas Islam Negeri Syarif Hidayatullah Jakarta 1436 H./2015 M

[19] Hartono, Arnicun Aziz. Ilmu Sosial Dasar. Jakarta: Bumi Persada. 1990.

[20] Husaini, Fahri, dkk. Bagaimana Agama Menjamin Kebahagiaan. Makalah Universitas Pamulang (UNPAM).

[21] Ikhsan, Fuad. Dasar-Dasar Kependidikan. Jakarta: Rineka Putra, 2005.

[22] Irfiana, Elly. "Kebahagiaan Menurut Agama Islam Dan Hindu Dharma." Tesis. Surabaya: IAIN Sunan Ampel Surabaya, 1998

[23] Isa S., Rifalzi. "Bab III Bagaimana Agama Menjamin Kebahagiaan?"

(http://ajengindah.log.fisip.uns. ac.id/wp- content/uploads/sites/261/201 6/12/watermark).

[24] Jalaluddin. Teologi Pendidikan. Jakarta: Raja Grafindo Persada, 2001.

[25] Kamil, Mustofa. "Teori Andragogi." Dalam Ibrahim, R. Ilmu dan Aplikasi Pendidikan. Vol. 1. Bandung: Imperial Bhakti Utama, 2007.

[26] Kasriyati. Membangun dan Membina Keluarga Sejabtera Mandiri. t.tp: t.p, t.th

[27] Kholil, Syukur. Metodologi Penelitian. Bandung: Citapusaka Media, 2006

[28] Kiswati, Suroya. Aljuwaeni Peletak Dasar Teologi Rasional dalam Islam. t.t.: Gelora Aksara Pertama, t.th.

[29] Kriyantono, Rachmat. Teknik Praktis Riset Komunikasi. Jakarta: Kencana Prenada Media Grup, 2010

[30] Ma'arif, Syamsul, "Konsep AlQur'an Tentang Keluarga Bahagia." Skripsi. Jakarta: Universitas Islam Negeri Syarif Hidayatullah Jakarta, 1431 $\mathrm{H} / 2010 \mathrm{M}$.

[31] Mahroes, Serli. "Konsep Rangka Bangun Teologi Pendidikan, Falsafah Pendidikan, Ilmu Pendidikan, dan Tafsir Pendidikan." http : L/serlimahroes. blogspot. co. $\mathrm{id} / 2011 / 06 /$ konsep-rangkabangun-teologipendidikan.html. (Diakses Selasa 22 Agustus 2017. 
[32] Meleong, Lexy J. Metode Penelitian Kualitatif. Bandung: Remaja Rosda Karya, 2011.

[33] Muhajir, Noeng. Metodologi Penelitian Kuantitatif. Yogyakarta: Rake Sarasin, 1996

[34] Muhajir, Noeng. Metodologi Penelitian Kuantitatif. Yogyakarta: Rake Sarasin, 1989

[35] Rakhmat, Jalaludin. Meraih Kebahagiaan. Bandung: Simbiosa, Rekatama Media, 2004.

[36] Resse, William L. Dictionary of Philosophy Religion. USA: Humanities Press Ltd, 1980.

[37] Rosyidin, Dedeng, Zaenal Mudzakir, dan Masor. Konsep Pendidikan dalam al-Qur'an, http:// file.upi.edu/direktori.pd

f. (Diakses tanggal 22 Agustus 2017).

[38] Rusydi, Teuku Eddy Faisal. Psikologi Kebahagiaan. Yogyakarta: Progresif Books, 2007.

[39] Sugiono. Memahami Penelitian Kualitatif. Bandung: ALFABETA, 2005

[40] Syafe'i, Imam. "Teologi Pendidikan: Epistemologis, Ontologis, Dan Aksiologis." Ijtimaiyya, Vol. 6, No. 2, 2013.

[41] Taufik, Zulfan. Ilusi dan Harapan: Pembacaan Humanisme Ali Shariati. Jakarta: Impressa, 2012, Cet I.

[42] Umar, Husein. Metode Riset Komunikasi Organisasi: Sebuah Pendekatan Kuantitatif Dilengkapi dengan Contoh Proposal dan Hasil
Riset Komunikasi Organisasi. Jakarta: Gramedia Pustaka Utama, 2002

[43] Undang-undang tentang SISDIKNAS dan Peraturan Pelaksanaannya 2000-2004. Jakarta: CV. Taminta Utama, 2004.

[44] Wardana, Anita Kusuma. "Filsafat dan Teologi." http:// filsafat.kompasiana. com/2011/01/20/filsafat-danteologi/, diakses dan diunggah selasa tanggal 22 Agustus 2017.

[45] Yunus, Mahmud. Kamus Arab Indonesia. Bandung: Hidakarya, 1990.

[46] Zed, Mestika. Metode Penelitian Kepustakaan. Jakarta: Yayasan Obor Indonesia, 2004. 